\title{
Kvinde-Evangeliet: Om Grundtvigs mandebilleder og kvindesyner
}

\author{
Af Uffe Jonas
}

Projektet er baseret på et toårigt stipendium fra Carlsbergfondet. Det er formålet at forfatte en monografi om N. F. S. Grundtvig ud fra en kønsfilosofisk, kønspolitisk og kulturhistorisk synsvinkel samt at placere Grundtvigs tænkning i spændingsfeltet mellem moderne og førmoderne europæiske erkendelsestraditioner, specielt med henblik på kønsforholdet. Projektet er tilknyttet Center for Grundtvigstudier, Aarhus Universitet og udgør samtidig det danske bidrag til det intereuropæiske forskningsprojekt Kristen Mandighed - et modernitetens paradoks: mond og religion i nordeuropaisk kontekst 1840-1940.

\section{Patriarken og de vise kvinder}

Anekdoterne om Grundtvigs mandighed og kvindeglæde hører til blandt de mest yndede og benyttede ved selskabelige lejligheder i de grundtvigske kredse. Men samtidig udgør hans gennem-erotiske livsopfattelse et stort set uoplyst lag af forfatterskabet. Det vil næppe være for meget at påstå, at det er lige her, fra hans personlige indsigt $\mathrm{i}$ kærlighedens organiske kildespring, at helhedssynet i forfatterskabet udspringer. Over alt iscenesætter han mødet mellem den nedstigende guddommelige kærlighedskraft (agape), der med tusind underfulde tegn påkalder sin mage her på Jorden. Og kønskcerligheden, den omfavnende opfindsomme, selvrådige, medrivende, og mangfoldiggørende eros, der forvikler sig fremad igennem historien i sin evige stræben tilbage mod himlen.

Grundtvig var på én gang indbegrebet af den klassiske patriark, pater familias, landsfader og kirkefader. Han var således mand nok til at anse sig selv for lovformeligt gift, ikke blot med sine tre på hinanden følgende koner, men med hele det danske folk og endda med kirken (den ene og udelelige), som han var udvalgt til profet for! Denne profetiske eller patriarkalske søjle, som indføjer Grundtvigs person og åndelige lederskab i en lang jødisk-kristen mandstradition, udgør, hvad man kunne kalde for den maskuline søjle i forfatterskabet. Det er i denne udfarende rolle som handlekraftig patriark, folkelig fører og fremsynet institutionsindstifter, han almindeligvis er blevet genkendt og anerkendt.

Men samtidig var Grundtvig dybt involveret i det kvindelige. "Blandt Kardinalværdierne i Grundtvigs Liv og Digtning indtager Kvinden saa fremtrædende en Plads, at hendes Betydning for denne 
Digters enestaaende Livsudfoldelse næppe kan vurderes for højt" (Stevns 1950, 72). Ikke blot var Grundtvig personligt en stor og trofast kvindeelsker, men hans mandighed er også gennemsyret af kvindelige idealer: samtale, visdom, poesi, medfølelse, indlevelse, ligeværdighed. Med en stærk maskulin patos fremhæver han gerne de kvindelige ynder, fortrin og værdier som de fremtidsbærende $\mathrm{i}$ en moderne verden. Det gælder ikke kun socialt og politisk, hvor hans historiske indflydelse kan spores, men nok i endnu højere grad på det filosofiske og spirituelle plan, hvor hans - set i forhold til samtiden - ganske overraskende positive kvindeopfattelse har sit egentlige udspring. Men til trods for mange spredte skitser og enkelte mere dybtgående forsøg, så er denne altgennemgribende kønslige og kritiske dimension i hans tænkning aldrig blevet gjort til genstand for en mere omfattende eller sammenhængende behandling. ${ }^{\prime}$

Det er denne afhandlings hypotese, at Grundtvig grundliggende var en universalistisk og europæisk tænker. At han fra sit på én gang humane og urkristelige synspunkt havde sans for styrken og illusionerne i det moderne gennembrud - herunder gennembruddet for et nyt og mere liberalt kvindesyn, som han da også selv bidrog kraftigt til. Endvidere er det en grundantagelse, at Grundtvig bør opfattes som mere universelt tænkende, mere filosofisk, europæisk og måske også en del mindre "folkelig", end det normalt antages. I det mindste udgør folkeligheden og den folkelige dannelse kun et - om end også afgørende nødvendigt - modningsstadium på vejen mod livets videre og dybere horisonter. Grundtvig opererede således inden for et klart formuleret værdihierarki, hvor kærligheden til fædrelandet kun udgjorde ét af leddene i en stadigt stigende tonerække af personlige, menneskelige og himmelske forbindelser. Folkeligheden og den nationale vækkelse stod rigtignok helt centralt $\mathrm{i}$ hans politiske virke, men den stod hverken først eller højest på hans åndelige værdiskala, hvor både humanismen ("menneske-ligheden") og kristendommen ("kriste-ligheden") står højere. Ingen folkelighed uden individualitet ("jeg-hed"), ingen menneskelighed uden folkelighed, ingen kristelighed uden menneskelighed. Det er essensen af Grundtvigs berømte motto: Menneske først.

\section{Fra Skolen for Livet til Skolen for Sang}

Dette værdihierarki gennemtrænger hele forfatterskabet. Det udmønter sig i en række forskellige genrer og diskurser, tilpasset forskellige lejligheder og formål; og det understøtter samtidig de forskellige institutionsdannelser, som i henhold til Grundtvigs omfattende skolevisioner med tiden skulle udspringe deraf, nemlig a) højskolen 
("Skolen for Livet"), som retter sig mod den nationale, statslige og folkelige dannelse, b) universitetet ("Skolen for Lyst"), som retter sig mod den videnskabelige, humane eller almen-menneskelige dannelse, og endelig c) kirke-skolen ("Sang-Skolen" eller "Skolen for Sang"), hvis særlige dannelsesområde er det, som udfolder sig i vekselvirkningen mellem det guddommelige og det menneskelige. Belysningen af den universelle Grundtvig må derfor tage udgangspunkt $\mathrm{i}$ hans egen klare skelnen mellem disse tre forskellige beskrivelsesniveauer. Lærings-regimenterne følger den organiske progression i de menneskelige livsaldre. De har ontologisk og irreversibel status og ligger for så vidt fast. ${ }^{2}$

For læseren er det imidlertid afgørende for forståelsen, at de forskellige regimenter holdes klart ud i deres indbyrdes forhold til hinanden. Som hovedregel er Grundtvig yderst distinkt i sin markering af de forskellige overgange. Men når han midt $\mathrm{i}$ sin tætvævede litterære praksis, og ikke mindst i de særligt nationalt ophedede øjeblikke - for eksempel i tiden omkring tyskerkrigene - iblandt fik udstrakt det folkelige regimente en del længere end det kan bære, så gør det kun kravet til læseren om altid at kunne fastholde og udskille dem endnu mere påtrængende.

Grundtvigs folkelige og nationale overvejelser, som gav inspirationen til den grundtvigianske bevægelse, giver i virkeligheden kun mening set $\mathrm{i}$ det overordnede filosofiske, humanistiske og spirituelle perspektiv, som han selv anskuede dem i. Den nationale vækkelse var i sig selv et internationalt fænomen, og Grundtvig var en universel tænker, kristen johannæer, kosmolog og videnskabsfilosof, både før og efter han blev folkelighedens nationale bannerfører. Der findes således omfattende aspekter af Grundtvigs tænkning og selvforståelse, som aldrig indgik i den grundtvigianske beskaring - sider, som blev overset, misforstået eller endog aktivt fortrængt som et nødvendigt led i den folkeligt-nationale perspektivforkortelse, der gik forud for grundtvigianismens etablering som historisk og politisk magtfaktor.

Set fra et kønsfilosofisk synspunkt kan man måske ligefrem påstå, at det er manden Grundtvig (højskolemanden, folketingsmanden, kirkemanden osv.), den folkeligt-nationale førerhund, patriarken og lovindstifteren, som er kommet til at skygge for en række andre, mere filosofiske, subtile, poetiske, hjertelige og for så vidt også kvindelige sider af hans væsen - sider, som snarere har at gøre med hans egen personlige tilblivelse som menneske, digter, tænker, ægtemand og kristen, end med hele den landsfaderligt udadrettede virksomhed, som udsprang deraf.

Hos Grundtvig står al menneskelig udvikling således i kvindelighedens, vækstens, fødslens og genfødslens billede. Lige fra 
sin pure ungdom opfattede han under inspiration fra romantikerne de forskellige menneskelige livsaldre som symboler på forskellige fremherskende sjæleevner - evner, der igen modsvares af de fremadskridende dannelses- og udfoldelses-muligheder, som knytter sig til deres kultivering. Således opfattede Grundtvig barndommen overvejende som fantasiens tid, ungdommen som følelsens, manddommen som forstandens. Og endelig alderdommen, der symbolsk må forstås som den sjælsberejste og dødsnære livsalder, repræsenterer eftertankens, selvindsigtens, kcrlighedens og visdommens kvaliteter. Det er dette sidste og mest fremskredne modenhedstrin, som - om hele historien går vel - skal kunne syntetisere og oplyse alle de foregående og således forvandle menneskets livsaften til en paradisdæmring.

\section{Det Stormenneskelige Levnedsløb}

Tilsammen danner disse ideal-typiske udviklingsfaser et forbilledligt livsforløb, som Grundtvig også kalder for "det Christelige Helteliv" eller "det Stormenneskelige Levnedsløb". Der er i virkeligheden tale om en historisk udfoldet Kristus-figur. Som han for eksempel udtrykker det i en prædiken fra 2. juledag 1838:

Christne Venner! Barne-Tro, Ungdoms-Ild, Manddoms-Kraft og Oldings-Viisdom, det er Elementerne i det Christelige Helteliv, som efterhaanden skal sammensmelte i den himmelske Kiærlighed, som er Fuldkommenheds Baand (GP XII, 106).

Den, som lægger sig i fuldkommenhedens bånd, det vil sige antager Kristus som sit aktive livsforbillede, vil således begynde at gennemløbe faserne $\mathrm{i}$ det kristelige helteliv i sit eget livs mere begrænsede målestok. Målet for den troende er at vokse som kristen til en Kristus. For Grundtvig er menneskets åndelige og hjertelige vækstmuligheder altså dybest set ubegrænsede. For den troende vokser træerne faktisk ind i himlen! Eftersom det er Kristus selv, den guddommelige sandheds og kærligheds inkarnat, der fungerer som modellen eller arketypen for den menneskelige dannelse til sandhed, storhed og skønhed (jf. $D V$ III, 17 ff.). Det er Kristus selv, der har ført det historiske muligheds-bevis og dermed sat målestokken for det kristelige helteliv.

I deres dannelseshistoriske følgerigtighed fungerer de forskellige livsaldre og erfaringsrum altså som forskellige faser i det stormenneskelige levnedsløb. Der er i virkeligheden slet ikke tale om noget enkelt menneskeligt livsforløb, men snarere om sjolelige aldre eller erfarings-typer, som igen afspejler sig i de forskellige fysiske modningsgrader: Person-lighedens (eller "Enkelt-mandens") dannelse er indskrevet som en forudsætning i folke-lighedens, som igen er 
indskrevet i menneske-lighedens og i kriste-ligheden som stadigt mere omfattende, stadigt mere fuldendte dannelsestrin. De forskellige livsaldre står ikke i modsætning til hinanden, men fungerer som distinkte - men tæt sammenvævede - betydningsregimenter, inden for den overordnede referenceramme, som er først menneskelig og så kristelig vækst. Suffikset: -lighed er fællesnævneren, som udtrykker den grad af jevvning, balancering eller sjælelig integration, som er idealet for tilegnelsen af de forskellige livsaldre og dannelsesområder.

For barnet er det kroppen og personlighedens elementære dannelse ("jeg-heden"), som står i centrum. Fantasien eller barne-troen er de uskyldiges naturlige vækstelement. Jegheden eller personlighedsdannelsen er målet. For ungdommen er det fællesskabsfølelsen, den folkelige eller sociale mandjævning, som er afgørende. Ungdoms-ilden er eros, den naturlige lidenskab for sandhed, skønhed og høje idealer, som stimulerer den naturlige vækst. Men som så let kan brænde over i afguderi, fanatisme og ørkengold bogstavtro. For manddommen er det de mere realistiske og almentmenneskelige egenskaber, evnen til forblive sig selv under skiftende ydre omstændigheder, at forholde sig i lige grad menneskeligt til sig selv og til alle andre, uden skelen til race, nationalitet eller partibog. Manddomskraften er jeg-kraften, den veludviklede vurderings- og kærlighedsevne, der binder personlighedens modstridende elementer sammen til en organisk helhed og tilføjer dem menneskelighedens dybde, fylde og vægt. Og endelig for visdomsalderen er det kriste-ligheden, de højeste guddommelige målestokke, som fører ind i den eskatologiske livsfase, som man også med Nietzsche kunne kalde for afgudernes ragnarok eller sandhedens time. Oldings-visdommen betegner den fremskredne fase i menneskets udvikling, hvor selvbevidstheden forankres i himlen, hvor døden bliver sanseligt og kropsligt nærværende, formerne slippes, alt det skjulte åbenbares, og hele menneskelivet oplyses i evighedens skær: "Jeg lever ikke, men Kristus lever i mig!" Det var vismanden Paulus' motto. Dannelsesmålet for hele den samlede menneskelige læringsvej kalder Grundtvig da også ligeud for "Kriste-Lighed" eller "Fuldkommenhed". Ligesom i den ortodokse tradition opererer han således med helliggørelsen som en særlig dannelses-kategori. Her er det herlighedsdragten, selve det jordiske fuldkommenhedslegeme, som skal anlægges og udvikles.

Dermed lagde Grundtvig også grunden til udformningen af sit progressive skolesystem med dets åndelige og pædagogiske regimenter til formidling af de forskellige livsovergange. Den skematiske præsentation af livsaldrene må som sagt ikke opfattes alt for snævert, som om de forskellige sjælelige egenskaber og dannelsesmål kun har gyldighed for bestemte aldersgrupper. For Grundtvig kan der aldrig 
være tale om nogen uoverstigelig modsætning mellem enkeltmandens personlige og folkelighedens samfundsmæssige dannelse. Men det ene er en organisk forudsætning for det andet, som igen danner grundlaget for den videre udvikling. Der er altså snarere tale om en gennemgribende erfaringsmæssig kontinuitet, formidlet igennem et antal historiske overgangskriser, hvor det forudgående, mere elementære dannelsestrin indoptages, bearbejdes og nedsænkes som en forudsætning i de senere. Den personlige og kropslige prægning, som finder sted $\mathrm{i}$ barndommen, $\mathrm{i}$ familien og i grundskolen indgår i modificeret og bearbejdet form som selve grundmaterialet i den folkelige og samfundsmæssige dannelse. Det er denne kritiske overgang mellem barndom og ungdom, mellem formynderi og personlig myndighed, som det har været højskolernes traditionelle opgave at formidle i form af en almen og praktisk indvielse til samfunds- og voksenlivet.

Men indvielsen til folkelighed er langtfra den sidste af de historiske og personlige livsovergange, som formidles i Grundtvigs progressive pædagogik. Den nationale krise, som det europæiske projekt har udløst, og som udspiller sig på dramatisk vis i disse år, svarer således ganske nøje til overgangen fra den folkelige til en mere human eller alment-menneskelig livsdimension. Det er denne kritiske overgang mellem det provinsielle og det universelle menneske i os alle, som det europæiske projekt sætter på spidsen. Og som med stadigt større tydelighed søges formidlet og formildet igennem opbyggelsen af en række overstatslige, mellemfolkelige og civile institutioner. I Grundtvigs særlige optik kan disse institutionsdannelser anskues som en slags eksperimentelle læringsfællesskaber til overbinding, ikke kun af de formelle statslige og lovgivningsmæssige modsætninger, men efterhånden også af alle forståelses- og kulturkløfterne. En fysisksjælelig overbinding svarende til menneskekroppens egen dannelse til manddoms- eller forstands-alderen. Og en vældig kultur-pædagogisk opgave, hvor vægten, efterhånden som projektet modnes, flyttes fra de rent materielle, formelle og økonomiske rammestrukturer (kroppen), for i stedet at lægges på de mere tværkulturelle, humane, videnskabelige og alment menneskelige lærings-elementer (sjælen). Det svarer til den udvikling, der i dag finder sted, bort fra den klassiske højskole, Skolen for Livet, som havde en rent folkelig dannelsesfunktion. Og henimod den mere poetisk videnskabelige eller kosmopolitiske dannelsesform, som ifølge Grundtvig skulle udspille sig på det frie fællesnordiske universitet, kaldet Skolen for Lyst (jf. Jonas 2003). Det nationale menneske, som var opladt af ungdommens og selvstændiggørelsens passionerede ild, skal nu kort sagt til at blive voksent.

Men ligesom der her er tale om en glidende historisk overgang mellem det folkelige og det menneskelige, så findes der heller ikke 
noget uoverstigeligt "spring", der skiller den humane erfaringsdannelse fra den egentlige kristelige spiritualitet. Hos Grundtvig vejledes og understøttes den menneskelige vækst helt bogstaveligt af Helligåndens gerninger, som er den skjulte, men allestedsnærværende livskraft, der formidler de kritiske overgange. Mottoet menneske først og kristen så er som skabt til at tage den varme luft ud af al opblæst kristen nationalisme, skrift-fundamentalisme og overspændt syndsbevidsthed. Grundtvig opererer ikke som Kierkegaard og hans hypersyndsbevidste efterfølgere med en række kritiske brud eller åndelige spring, der adskiller regimenterne uhjælpeligt fra hinanden, drukner den menneskelige udvikling i kritisk selvbevidsthed, og som i praksis dømmer menneskelivet uden for Guds Rige. Men snarere med en jævn - om end også krisefyldt - historisk og erfaringsmæssig kontinuitet. Hvor Helligånden er en potentielt nærværende og understøttende faktor gennem samtlige forvandlinger og erfaringstrin. At benægte eller forhindre den menneskelige vækst er for Grundtvig det samme som at synde mod livet, at hæmme det guddommelige åndedrag. Den eneste synd, for hvilken der - i sagens natur - ikke findes nogen tilgivelse.

\section{Den eskatologiske doemring}

Overgangen fra menneskelivet til kristenlivet - altså til det liv som rækker ud over det rent menneskelige og ind i højere riger, er den dybtgående erfaringskrise, som med en velkendt formulering fra Johannesevangeliet fører fra det gamle menneskes død og til fødslen af det ny. Udviklingen af det humane, af menneske-ligheden, er den helt naturlige og nødvendige forudsætning for udviklingen af det sprirituelle eller kriste-ligheden, som er formen for det nye menneske. I virkeligheden danner væksten ud over vores naturlige forvanskninger og indskrænkninger og ind i det skabende, det hellige og det mirakuløse, et helt nyt regimente, et nyt rige, midtvejs imellem det guddommelige og det menneskelige. Grundtvig taler i lighed med ortodokse tænkere om udviklingen af det gud-menneskelige som et særligt regimente. Det er Riget for det genrejste menneskeliv, som Kristus - gudmennesket - selv inkarnerede, og som forudses som de troendes sejrsdragt i Det Nye Testamente. Der er altså tale om en ny refleksiv og objektiv orden, en menneskelig udviklingsmulighed, som forudsættes i evangelie-beretningerne, men som endnu ligger i kim. Også i denne henseende gælder devisen, menneske først - kristen så.

Den daglige overbinding fra det, som Grundtvig kalder for det gammelmenneskelige til det nymenneskelige, foregår ikke kun i kirken og menigheden, men nok så meget i hjemmet, blandt kærlige ægtefolk. 
For det er ikke nødvendigvis de bogstaveligt rettroende, men snarere de elskende, der er de sande indbyggere og medbyggere i det ny Jerusalem. Det er her, i de usynlige sprækker mellem nadvergangen, salmesangen og ægtesengen, at man skal finde sporene af den skjulte menighed, Skolen for Sang, Således, hævder Grundtvig, kan vi i Danmark spore kimen til:

en mageløs Kicerlighed saavel i Forholdet mellem Forceldre og Børn som mellem Mand og Kvinde, og da disse ligesaavel er den christelige eller nymenneskelige, som den hedenske eller gammelmenneskelige Kiærligheds Grund-Forhold, saa maa det findes rimeligt nok, at naar vi Danske christnedes, det da snarest vilde være hos os, at Lyset skulde opgaae over Agteskabets og Christendommens indbyrdes Sammenhæng (VU VI, 131).

Grundtvig udpeger således de allermest intime menneskelige relationer, og det allermest nærliggende af alle livsrum, selve familien med dens iboende køns-, kærligheds- og generations-konflikter som den kristelige livsoplysnings privilegerede sted. Bemærkelsesværdigt er det, at han her, i lighed med kirkekampens Kierkegaard, om end på en langt mere afklaret og opbyggelig måde, fremskriver danernes kristning, idet han sprogligt og retorisk placerer begivenheden i en nærmere bestemt fremtid (futurum exactum). Ligesom han fastlægger stedet og formen for en sådan kommende kristelig oplysning, øjeblikket "naar vi Danske christnedes", temmelig præcist, nemlig til det åbenbaringens øjeblik, "hvor Lyset opgaar over AEgteskabets og Christendommens indbyrdes Sammenhæng”. Sande kristne bliver vi altså først, når engang et virkelig hjerteligt indlevet og forklarende lys bliver kastet over de mest naturlige eller "Grund-Menneskelige" relationer. Såsom ægteskabsforholdet "mellem Mand og Kvinde" og kærlighedsforholdet "mellem Forældre og Børn". Netop de allernærmeste livsforhold, hele det kvinde-, køns- og kropsnære erfaringsrum, som ægtemanden Grundtvig levede og åndede midt i. Men som munkemanden Kierkegaard kun havde platonisk afbrudte og ulykkelige erfaringer med.

Den særlige pædagogiske opgave for Skolen for Sang er således udviklingen af en kristen dannelses-kultur, som kan formidle overgangen mellem det gammel- og det nymenneskelige. Grundtvig skelner i sin ægteskabsteologi mellem det naturlige kærlighedsliv, som han kalder for det "grund- eller gammel-menneskelige", og hvis hovedsigte er selve den fysiske forplantning og yngelpleje, og så det egentlige kristne kærlighedsliv, som svarer til de mere altruistiske livsrelationer, som er frigjort fra de snævre kønslige og slægtslige definitioner, og som han derfor også kalder for de "nymenneskelige". Det svarer $\mathrm{i}$ teorien til overgangen mellem den naturlige og den 
åbenbarede teologi. Hvor den første beskæftiger sig med spørgsmålet om det naturlige, det vil i praksis sige med regulering af kønsmoralen. Mens den anden beskæftiger sig mere vidtrækkende og perspektivrigt med kønnets filosofiske, teleologiske og eskatologiske betydning. ${ }^{3}$ Hos Grundtvig er kønstænkningen altid baseret på det naturlige tiltrceknings- og forplantnings-perspektiv, som udgør naturgrundlaget. Men den er samtidig konsekvent indlejret i det radikale eskatologiske oplysnings-perspektiv, som sætter hele kønslivet på den åndelige forvandlings og det kreative nybruds spidser. Hvor Adam, det edeniske menneske, betegner menneskets komplicerede forhistorie og personligheds-dannelse, dets første natur, så er Kristus den anden. Han repræsenterer det endnu ukendte og uudfoldede. Han er fremtidsmålet, Jerusalems-mennesket, den neurotiske jegheds forløser, den opstandne og forklarede Adam. Det var ikke mindst til formidling af disse grundforhold, at Grundtvig skrev Den Christelige Børneloerdom og digtede sit Sang-Vark til den Danske Kirke. Med hele den iboende kosmologi, den kristelige krops-, køns- og kirkeforklaring, der skulle danne grundlaget for den syngende menighed, og dermed for "KirkeSkolen", forstået som en egentlig kristen dannelses-kultur.

Hos Grundtvig var den naturlige og den guddommelige elskov forbundet på den mest intime og uadskillelige måde. For ham var der ingen afgørende modsætning mellem den omfavnende erotiske og den tilbedende (teistiske) kærlighed, sådan som man ellers typisk finder det i den platonisk munkeagtige kristne kultur, og litteratur. En kultur som ellers oftest har sat forsagelsen af verden højere end indlevelsen i den. Den selvdistancerende, selvoverskridende kærlighed til Gud højere end den mere nænsomme og kvindelige hengivenhed eller med-lidenskab (com-passio) for livet og næsten. Grundtvig opererer slet ikke med nogen skarptskåren dualisme mellem ånd og kød. For i livet er de netop bundet sammen. Ånden er inkarneret, og det dunkle kød rummer i sig selv et potentiale for oplysning, en særlig åndelig livsdybde og kødelig livsforklarelse, som ikke kan tilegnes på nogen anden måde. For Grundtvig er det inkarnationen med alt, hvad den indebærer af dunkle drifter, himmelske længsler og skingrende modsætninger, der bør være udgangspunktet for den kristelige forståelse. Erfaringerne af den himmelske kærlighed bygger direkte videre på det erotiske naturgrundlag. De udtrykker den samme elementære eksistensfryd og livsbekræftelse, blot $\mathrm{i}$ en mere ophøjet, intensiveret og forklaret form. Udvidelsen af det åndelige råderum sker ikke på bekostning, men netop $i$ kraft af den erotiske kærlighed. Således intensiveres forplantningsevnen radikalt, idet den gradvis løsnes fra de snævre bindinger til intimsfæren, og antager stadigt mere omsiggribende, kreative og næstekærlige former. At også kødet har sin plads i paradiset leverede 
Kristus selv beviset på, dengang han opstod i kødet, og hele verden opstod med ham.

Grundtvig hører med andre ord slet ikke til inden for den almindelige kønsforskrækkede munke-kultur - hele den monastiske og augustinsk prægede kønsmoral, som i en vis (om også kun udvendig) forstand danner hovedstrømmen i kristen tænkning. Han tilhører snarere den oprindelige jødiske og urkristne skabelsesmystik, som var solidt forankret i ægteskabet og derfor langt mere jordnær, erotisk og kropsbevidst. Som kristen skabelsestænker indskriver han sig i den særlige erkendelses-linje, der rækker fra de gammeltestamentlige visdomsbøger over kirkefædrene Johannes, Paulus og Irenceus til middelalderens store skabelsespoeter Dante, Aquinas, Eckhart, Hildegard og Mechtild. Ligesom der er klare forbindelseslinjer fra Grundtvig til moderne kristne kosmologer som Teilhard de Chardin (1968), A.N. Whitehead (1995) og den meget nulevende Matthew Fox (1988 og 2000). Få har således gjort mere for at genopdage og revitalisere denne særlige skabelses-mystiske tradition end netop Matthew Fox. ${ }^{4}$

Tilsvarende finder man i centrale dele af den østkirkelige tradition et syn på Eros, som er nært beslægtet med Grundtvigs, om end forståelsen pga. kloster-asketicismens mellemkomst oftest har været præget af en høj grad af idealisering og især rettet mod de mere 'kropsløse' kosmologiske aspekter. Men eros er i det mindste anerkendt og medtænkt som en guddommelig kraft. Det er forbindelsen til den oprindelige jødisk-kristne visdoms-tradition, som er bevaret og slår igennem i det østlige syn. På trods af asketicismens traditionelle negative syn kroppen og kønnet, så har man bevaret Sophia-forståelsen og dermed også sansen for Eros langt bedre i østen end i vesten. Det er den evige hymne til skabelses-underet, den erotisk-kosmologiske livsåre, der løber gennem de gammeltestamentlige visdomsbøger (ikke mindst Højsangen) til Johannes og Irenceus, og som man genfinder mere eller mindre usvækket hos kirkefædrenene. For eksempel hos Johannes Chrysostomos (1986), Symeon den nye Teolog, Ephraëm Syreren og Maximus Bekenderen. Eller endnu tydeligere hos moderne fornyere af den ortodokse tradition såsom Vladimir Soloviev (1997), Sergei Bulgakov (1993), Pavel Florensky (1997), Nicolas Berdyaev (1945, 46 og 62), Paul Evdokimov (1994 og 2001) og Philip Sherrard (1976). Sidstnævnte var medudgiver af den ortodokse traditions hovedskrift, Philokaliaen (1981). Hos disse tænkere sker der en fornyet fremdragelse af eros-tankningen, og samtidig en moderne vending bort fra asketicismens idealistiske og asketicistiske overdrivelser og tilbage mod kroppen, sanserne, lysten og sexualiteten som fuldgyldige udtryk for den guddommelige skaberkraft. Hvad de 
udfører, er en genrejsning af den jødiske skabelsesmystik på ortodoksiens grund, men på moderne præmisser. En bevægelse mod jorden, livet, sanserne og medmenneskeligheden, som er meget nært beslægtet med den, som Grundtvig udfører inden for protestantismen.

Walter Schubart (1887-1941), som repræsenterer den samme østkirkelige erkendelses-tradition, har måske formuleret denne intime og ubrydelige forbindelse mellem religion og erotik bedre end nogen anden. Idet han sammenstiller den lodret tilbedende (teistiske) og den vandret sammensmeltende kærlighed $\mathrm{i}$ en historisk opadstræbende korsform:

Tilbedelse og sammensmeltning er de to former, som den forløsende kærlighed udtrykker sig i. (...) Men tilbedelsen er hengivelse til en overordnet, sammensmeltningen til en sideordnet værdi. Tilsvarende frembringer forløsningsmotivet såvel den tilbedende eller teistiske som den omfavnende eller mystiske kærlighed i religion og erotik. (...) Tilbedelsen er en religiøs, sammensmeltningen en erotisk kategori. Det hører til religionens egenart, at mennesket bøjer sig ærbødigt for et højeste væsen. At et væsen stræber efter at vokse sammen med et andet til en uopløselig enhed er grundprocessen i det erotiske, om end ikke helt i det seksuelle. Med tilbedelsen trænger et religiøst element ind i erotikken, med sammensmeltningen trænger et erotisk element ind i religionen (Schubart 1969, 135 ff.; min oversættelse).

Det er en sådan erotisk-spirituel grundholdning, med rødder i den oprindelige jødisk-kristelige skabelses-mystik, som man genfinder i Grundtvigs kærligheds-opfattelse. Han benægter på ingen måde eksistensen af højere og renere kærlighedsformer end den fysiske. For i sin reneste og mest universelle form er eros i sig selv en fuldstændig ubesmittet og uindskrænket kosmologisk lidenskab. Med Maximus Bekenderens (580-662) ord fra Philokaliaen, så må Eros dybest set betragtes som en indre bevægelse i Guddommen selv. Det er den intense kærligheds-længsel, den åndelige tiltrækning eller tyngdekraft, som sætter Skaberen i bevægelse mod skaberværket, og skabelsen i bevægelse tilbage imod Skaberen. Hele skabelsesprocessen, den kosmologiske evolution, ja Skaberen selv, er således drevet af den erotiske drift mod den anden:

Teologer kalder nogle gange det guddommelige en erotisk kraft, nogle gange kærlighed, nogle gange det, som man intenst længes efter eller elsker. Følgeligt, forstået som en erotisk kraft og som kærlighed, så er det guddommelige selv genstand for bevægelse; og som det, man længes intenst efter eller elsker, trækker det alt hvad der er modtageligt for denne kraft og kærlighed ind imod sig selv. For at udtrykke det klarere: det guddommelige er selv genstand for bevægelse, eftersom det udvirker en indre tilstand af intens længsel eller kærlighed i dem, som er modtagelige derfor. (...) Med andre ord, det bevæger andre og 
bevæges selv, eftersom det tørster efter at blive tørstet efter, længes efter at drage længsel imod sig, og elsker at blive elsket (Sherrard 1981, II, 280; min oversættelse).

Således betragtet er den erotiske tiltrækning en grundkraft i universet. Det er den immanente guddom, den bevægede bevæger. Set i modsætning til den teistiske eller transcendente guddom, Faderen, som forbliver på abstrakt afstand af sit eget skaberværk, tilbagetrukket, ulidenskabelig, ubevæget, udeltagende. I den forstand var Kristus som lidende, handlende og favnende væsen indbegrebet af den forklarede Eros, den bevægede, den indlevede og medlevende kærlighed, og Grundtvig sidestiller da også flere steder de to. For eksempel i Dansk Ravne-Galder (1866), hvor han sammenligner de forskellige mytologier og kulturkredses forskellige udgave af det stormenneskelige levnedsløb.

I Indien kunne sørgende enker således engang blive tvunget til at gå på bålet sammen med deres afdøde ægtemænd. Men denne grusomme tradition, kaldet sati, er kun en sørgelig afglans af den åndelige sandhed, at sandheds-elskerne, hjertets højbårne kongedøtre, altid har næret evig kærlighed til deres åndelige helteskikkelser, for hvem de gladeligt går i ilden. Ordet sat betyder bogstaveligt: sand varen - og med den kvindelige endelse - $i$, henviser det netop til selvopofrelsen, den lutrende forvandling, som selve essensen af $k v i n d e l i g$ - og det vil for Grundtvig sige menneskelig - væren. Sjælens urdrift er mod ild. Og det gælder, uanset om helten hedder Eros eller Kristus:

Thi Hjerter som for Aander slaae,

Og kan med Ord henrives,

De er paa alle Hjertesprog

Høibaarne Konge-Døttre,

Som for den Kæmpe, de har kiær, Gaaer syngende i Ilden;

Dusjantus hist er Heltens Navn,

Her Habor eller Balder,

Han Eros hedd i Grækenland,

I Palæstina Christus;

Og der som ellers ingensteds

Den Sandhed kom for Dagen,

At Ilden til hvert Balders-Baal,

Som blusse skal paa Jorden,

Maa ulme først, som lille Gnist,

Hos os i Hjertekamret,

Hvor, efter Hindu-Kongens Ord,

"Sit Brænde-Ved den venter".

(US X, 446 f.) 
Men eros er ikke kun en kosmologisk lidenskab. Den indeholder ikke kun hjertets brændende trang til selvoverskridelse, som er en drift mod ild, en dødsdrift. Men den inddrager hele menneskelegemet, det konkrete jordeliv og dermed hele kosmos i den intense drift mod forening. For Grundtvig er det afgørende, at intensiveringen og forklarelsen af de menneskelige kærlighedsevner bygger på styrken og erfaringerne fra de nære og intime livsrum. De kvindelige elementer, Jorden og Vandet, må inddrages for at køle og dæmpe den ophedede og grænsesprængende sandheds-lidenskab. I sin rene idealistiske form kan overskridelsesdriften, ungdoms-ilden, let udvikle sig destruktivt. Til drengeagtig dødsleg, åndelig dødekult og militærindustrielle komplekser. I sin karakteristiske verdensforsagende foragt for kvinden, kroppen og kønnet har kristendommen ofte selv ageret som en voldelig idealistisk dødekult. Men himmeriget bygges ikke på afkald alene. Køns-forvandlingen sker ikke i et halsbrækkende lodret munkespring ud af denne verden, men gennem en gradvis metodisk udvidelse og metaforisk bearbejdelse, der langsomt, men sikkert flytter vægten fra det jordiske mod det himmelske, fra det velkendte mod det ukendte, fra det adamiske mod det kristelige. Den åndelige ild må vækkes sagte og nænsomt, skabe oplysning - ikke kun omkring hovedet, men inde fra selve hjertekulen, fra menneskekroppen. Blive til den daglige organiske vækstkraft i tanker, følelser og adfærd, der får den enkelte til at vokse ind mod sit heltebillede og selv antage stormenneskelige former. Ellers bliver mennesket hurtigt stegt levende ligesom enkerne $\mathrm{i}$ Indien. Kun ved at fastholde sig selv på sit menneskelige naturgrundlag bliver den kristne kærlighed i stand til at udfolde sig på en harmonisk, det vil sige åndeligt balanceret, historisk formidlet og organisk forsvarlig måde. Idet den tilstræber at udvide omfavnelsens, nærhedens og ømhedens principper, og efterhånden give dem en mere fleksibel, reflekteret og almenmenneskelig karakter.

Grundtvig sammenfatter tilblivelsen af disse højere og mere upartiske kærlighedsevner i betegnelsen søskende-karlighed eller philadelphia. Sådan som mange andre kristne tænkere, både i og uden for de ortodokse kirkesammenhænge, har gjort det, både før og efter ham. Philadelphia er således navnet på den sjette af menighederne i Johannes Abenbaring, og det er samtidig navnet på den kristne menighed, som Grundtvig håbede med tiden skulle forme sig $\mathrm{i}$ hans egne fodspor.

Det var denne åndelige Kirke-Skole, til dannelse af den sjette, det vil sige den nordiske menighed, som skulle have været selve himmelkronen på det grundtvigske skoleværk. Men ligesom med universitetsdrømmen, Skolen for Lyst, der i sin tid druknede i overspændte folkelige forventninger, så må denne storslåede kirkedrøm endnu siges 
at have fremtiden for sig. For spørgsmålet er jo, om Grundtvigs karismatiske, kreative, Helligåndsbegejstrede og Maria-orienterede kirkevisioner nogensinde er blevet blot tilnærmelsesvis realiseret. Det afgørende i denne sammenhæng er imidlertid ikke så meget folkekirkens aktuelle tilstand, som nok lader en del tilbage at ønske set fra et livs- og skabelses-orienteret synspunkt. Men det er snarere selve opbygningen af den sfæriske logik, de særlige symbolske ordener, som Grundtvig tilskriver de forskellige regimenter, og som ligger til grund for de forskellige skoledannelser.

Heri indtager Skolen for Sang nemlig en ganske bestemt arketypisk eller real-symbolsk funktion, som kronen og forklaringen på hele skoleværket. Og det uanset om kirken nu lige for tiden er i stand til at leve op til sit eget høje formål eller ej. Tilsammen danner disse stadigt voksende betydnings- og erfarings-cirkler nemlig en hel lille kristen antropologi. Det er denne særlige kristne udviklings-lære og historiefilosofi, som Grundtvig kalder for det stormenneskelige levnedsløb. Fordi det hele samler sig i billedet af menneske-kroppen, der vokser indefra $\mathrm{i}$ billedet af det fuldkomne menneske. Det kan illustreres og sammenfattes således:

\section{Livsaldre}

alderdom

manddom

ungdom

barndom

\section{Læringscentre}

skolen for sang skolen for lyst skolen for livet skolen for leg

\section{Dannelsesmål}

kriste-lighed / fuldkommenhed menneske-lighed folke-lighed person-lighed

Erkendelsesevner
visdom / vished
forstand
følelse
fantasi / vilje

\section{Erkendelsesevner}

visdom / vished

forstand

følelse

fantasi/vilje

\section{Eros, kønskamp og kosmologi}

Disse erfaringssfærer og overgange er vigtige at holde sig for øje, ikke mindst når man som her læser Grundtvig med et universelt sigte. Det vil således være et overordnet mål for denne afhandling at belyse Grundtvigs kønsfilosofi ud fra den skabelses-orienterede erkendelsestradition, han hører hjemme i. Samtidig vil jeg forsøge at bestemme Grundtvigs historiske og politiske betydning som det, man kunne kalde for et "modernitetens paradoks". Det vil sige, som et meget indflydelsesrigt, men også stærkt sammensat kristent forbillede under det vældige bevidsthedsskred, som etableringen af den moderne 
borgerlige samfundsform udgjorde. Grundtvig synes selv at inkarnere mange af sin samtids kønspolitiske brydninger. Udspændt imellem liberale og gammelkristne impulser fremstår han på én gang som indbegrebet af den borgerligt patriarkalske samfundsorden, hvor manden var kvindens hoved - og som en stærk støtte for kvindesagen! Dog helst $\mathrm{i}$ dens mere åndelige og samfundsbevarende betydninger. Hans historisk set enestående, om end også noget paternaliserende støtte til Mathilde Fibiger, forfatteren af Clara Raphaels Breve (1850), den første feministiske roman på dansk, taler da også for sig selv.

Grundtvigs væsentligste bidrag til den kønspolitiske udvikling ligger dog nok snarere på det filosofiske og åndelige end på det praktiske og direkte reformatoriske plan. Noget større kampskrift til omvæltning af den huslige rollefordeling har han i hvert fald ikke bidraget med. På hjemmefronten i det lutherske hushold indtog han sin naturbestemte plads for bordenden. Helt efter datidens borgerligtpatriarkalske mønster, hvor manden som familieoverhovedet var den lovgivende, og hustruen, som legemliggjorde det hjemlige hjerte- og husrum, så at sige den udøvende magt. Grundtvig skelner i fuld romantisk stil mellem manden som åndens og kvinden som hjertelighedens naturåbenbaring. Men han driver denne tidstypiske skelnen langt ud over den blotte naturbestemmelse og ind i et kreativt dybde-psykologisk og kosmologisk dannelses-perspektiv, som må være en af de mest avancerede kønsbetragtninger i hele 1800-tallet, også set i internationalt perspektiv. Gennem sin - efter samtidens androcentriske målestok - helt ualmindeligt høje agtelse for kvindekønnet, har Grundtvig således bidraget med en mængde af symboliseringer, hvor der lægges stor vægt på kvindens særlige sjælelige værdighed og hjertelige værdier og på kønnenes komplementære og ligeværdige betydning. Og han har dermed skabt et omfattende symbolsk potentiale, en righoldig fond af fremsynede formuleringer, som efterkommerne - ikke mindst de kvindelige - har kunnet drage både menneskelig og politisk nytte af. For eksempel i kampen for indvielsen og accepten af kvindelige præster og biskopper. ${ }^{5}$ En kamp, som endnu står på, om end nu fortrinsvis uden for Danmark, i den langt større europæiske og økumeniske skala.

Sprogprofessoren Peder Skyum-Nielsen har for nyligt påpeget Grundtvigs betydning for ligestillingen og den særlige samfundsmæssige dynamik, der fulgte med den. Han opfatter det moderne fleksible og kreative danske samfund som et af udtrykkene for den særlige pragmatiske balancegang mellem kønnene, som Grundtvig i sin tid lagde grunden til:

Hans forståelse af samspillet mellem det traditionelt mandlige foretagsomhed, flid, disciplin - og de mere kvindelige, kærligheds- 
mæssige og blødere værdier tror jeg, vi i allerhøjeste grad nyder godt af nu. Det har givet os en smidighed, en fleksibilitet, som er nødvendig, når vi skal tilpasse os og stadigvæk være førende og kreative, fordi kreativitet $\mathrm{i}$ høj grad knytter sig til den dialektik mellem det maskuline og det feminine (Skyum-Nielsen 2006, 2).

Det er et tilsvarende dobbeltperspektiv på kønnet, der ligger til grund for denne afhandling. Grundtvigs betydning som kønsteoretiker og reformator ligger netop i hans instituering og symbolisering af denne særlige kønsdialektik, der, som han selv forudså det, måske nok har gjort danskerne til et mindre maskulint udfarende og erobrende, men til gengæld også noget mere smidigt (omstillingsparat, som det hedder), kreativt og innovativt folkefærd end de fleste. Dette har vist sig at være en stor konkurrencemæssig fordel i videns- og informationssamfundet, som netop baserer sig på kvindernes adkomst til arbejdsmarkedet, kønnenes indbyrdes balancering, og på individets frigørelse fra de traditionelle slægtsmæssige, kulturelle og nationale bindinger. Hvad man også kunne kalde for patriarkatets afvikling.

Indgangen til videns- og informations-samfundet, betyder overgangen til et langt større, mere universelt, refleksivt og potentielt set også kontemplativt livsrum. Betragtet som en historisk-eskatologisk overgang betegner kvindefrigørelsen således indgangen til den livsalder, som Grundtvig kalder for vidskabens (visdommens) eller eftertankens, og som nyere samfundstænkere, for eksempel Anthony Giddens, har betegnet som den refleksive samfundstype. Det er i Grundtvigs generelle højagtelse af kvinden og i hans omfattende filosofiske og poetiske produktion, som netop beskæftiger sig med kønsligheden i et sådant overordnet kosmologisk, visdoms- og samfunds-perspektiv, at man skal søge kimen til denne slående fremsynethed. Man kan altså, på trods af Grundtvigs alfaderligt langskæggede fremtoning, og på trods af det, som Elin Appel meget rammende har karakteriseret som højskolernes "senpatriarkalske system", måske ligefrem hævde, at afviklingen af dette system, frigørelsen fra de traditionelle kønsroller har ligget iboende som en udviklingstendens i det folkelige og nationale projekt lige fra starten (Appel 1978, 7).

Men Grundtvigs kønstænkning rækker langt videre end til samtidens og efterkommernes kønspolitiske konflikter. Den antager også en filosofisk og kosmologisk dimension, som det er en vigtig opgave at kaste lys over. Hos Grundtvig fremstår selve universet således kønsligt bestemt, måske fordi kærligheden selv er det. Hans forfatterskab er opladet med køns- og kærlighedsrelationer, så det ikke kun er spændingsforholdet mellem mand og kvinde, men snart sagt er alle livets forhold, der røres og berøres af den erotiske urkraft. Selve gudsforholdet fremtræder hos Grundtvig som en erotisk opladet 
relation. Ifølge Grundtvig blev mennesket oprindeligt skabt i Guds billede, hvor adskillelsen mellem kønnene slet ikke findes, eller hvor den alene har en pædagogisk, provisorisk og for så vidt illusorisk karakter.

Den grundliggende adskillelse, som både sproget og kønnene er underkastet, beskrives i Det Gamle Testamentes Mosebøger som følgen af en hel stribe af menneskelige fald, hvoraf det første og væsentligste er det, der fører til kønsadskillelsen mellem Adam og Eva. Det paradisiske menneske var oprindeligt et helt og udelt væsen, skabt i Guds eget udelte billede. Sønderdelingen af dette oprindelige androgyne eller adamiske menneskebillede $\mathrm{i}$ to hver for sig kun menneske-lignende halvdele, der er dømt til at søge det tabte i sig selv hos den anden. Urbilledet (arketypen) og lignelsen, den ufaldne og den faldne verden, er de to modstridende livsbilleder, som gennem verdens-historiens exodus må bringes i fornyet samklang. Ligesom manden og kvinden må genforenes i kærlighed, for at mennesket igen kan blive til et helt og ubrudt væsen. Køns-adskillelsen kan derfor ikke være menneskets egentlige eller oprindelige tilstand, men er alene til som et lærerigt provisorium, et historisk indgroet og tungt fordøjeligt naturgrundlag, som efterhånden har antaget skæbnens ubønhørlige karakter.

Men det er netop denne kønslige skæbne, selve grundspaltningen i mennesket, den adamiske brist, som Kristus har overvundet. At blive kristen betyder at bearbejde og gradvist omgøre enhver af de provisoriske adskillelser i den faldne verden, inklusive kønsadskillelsen, med sandhedens og kærlighedens altgennemtrængende kræfter. Det tabte gudsbillede kan kun hjemføres igennem en sådan metodisk indre bearbejdelse, udsoning eller udtoning af kønsadskillelsen, af væsensforskelligheden siden Adam og Eva. Gudsrigets genoprettelse og tilsynekomst (parousiaen) afhænger således af udviklingen $\mathrm{i}$ forholdet mellem manden og kvinden. Eller i videre forstand af balancegangen og integrationen mellem de maskuline og de feminine elementer i skaberværket. Og i denne vældige oplysningsproces udgør den bevidste og ubevidste kvindefortrængning gennem årtusinders patriarkalsk stammekultur en særlig nedgroet og hårdnakket modstandslomme. En systematisk skævvridning af verdensbalancen, der rækker forstyrrende og deformerende helt ind i skabelseselementerne.

Grundtvigs kosmologi og teologi er således gennemtrukket af symboler på mandighed og kvindelighed, frugtbarhed og avlekraft, himmel og jord, Kristus og menighed, sol og måne, ånd og krop, lys og liv. Det erotiske element er allestedsnærværende og rækker sågar helt ind $\mathrm{i}$ himlen. Selve universet blev skabt i det frugtbare samspil imellem kønslige modsætninger. Faderen ledsages lige fra begyndelsen i sin 
skabergerning af Sophia, skønhedens og visdommens stemme. Ordet, som omfatter alle skabelsens arketyper, den overordnede matrice eller hensigt, ledsages hos Grundtvig (ligesom i den jødiske mystik) af Røsten, der rummer alle de konkrete betoninger, alle de individuelle særtræk, som giver ophav til livets fylde og mangfoldighed. Og Helligånden, hjælperen og budbringeren, menneske-sjælens beliver, befrugter og beriger, dannede som bekendt par med Jomfru Maria. Endog den kristne treenighed af Fader, Søn og Helligånd finder hos Grundtvig sit jordiske og symbolske modstykke i den kvindelige treenighed af Moderen, Datteren og Agtehustruen (Moder, søster, elskede).

Også kirkegangen med alle dens sakramentale elementer er for Grundtvig en erotisk opladet situation med omfattende kønslige og kosmiske implikationer. Grundtvig var først og fremmest pinsekristen. Skønt hans indlevelse og indsigt i de øvrige liturgiske årstider og deres symbolik ikke er mindre omfattende eller dybsindig, så er hele hans skabelses-teologi orienteret mod de åndelige vækstkræfters udgydelse i forårsunderet. Hver enkelt af faserne i det liturgiske år gennemspiller menneskehedens forhold til det levende kosmos fra en ny synsvinkel. Det er genoprettelsen af det afbrudte eller forstyrrede kærlighedsforhold mellem Gud og menneske, himmel og jord, mand og kvinde, der er gudstjenestens egentlige liturgiske formål. Hvor ånden stiger ned, bliver mennesket i sin overstrømmende kærlighed til Gud og medmennesker gjort helt og udelt, det vil sige ånds-ncervarende igen.

Helligåndens udgydelse ved pinseunderet betegner netop en sådan åndelig overvindelse, ikke kun af de sproglige og kulturelle forskelle og barrierer, men også af de kønslige. I gudstjenesten gennemspilles forholdet mellem Kristus og menigheden arketypisk som det forklarede kønsforhold. De naturlige og grundmenneskelige relationer, ægteskabet, kønskærligheden og forældrekærligheden gennemlyses af en langt større og dybere kærlighed, som forvandler dem i sit eget lysende og levende billede. I Grundtvigs særlige udlægning betød åndens nærvær ved pinseunderet således en øjeblikkelig, om end også kun midlertidig genrejsning af disciplene til det tabte paradisiske eller androgyne stade.

Når grundtvigianere gerne synger så buldrende højt i kirken, så er det er altså ikke blot for salmernes og den tvivlsomme skønsangs skyld. Det er for at fastholde opmærksomheden på det afgørende: at livet har sejret, at døden er overvundet. At verden er genoprettet. At mennesket er blevet et helt og udelt væsen igen. Kristus, brudgommen, fungerer således som modellen for det nye menneske. Han er den nye og forklarede udgave af generations-væsenet, den jordiske Adam. Og Han lover den samme forklarelse til enhver. Himmeriget er ikke noget 
eksklusivt og utilnærmeligt foretagende, men ganske nærværende, noget helt konkret, kropsnært og livsforvandlende. Det er det åndedrag, der forbinder det højeste med det dybeste. Kærligheden er den opløftende og forvandlende kraft, der rækker igennem og hinsides alle kønslige, regimentale og sociale forskelligheder. Samånder det høje med det lave, det ydre med det indre, det mandlige med det kvindelige. Kristus er Ordet, der synger verden til live, til barnlig uskyld, glæde og leg igen. Til skaberfryd og kønslig ubekymrethed, som på skabelsens allerførste dag. Hvor alt endnu var muligt. Hvor vækstkraften var udelt og uendelig. Hvor universet og mennesket blev velsignet som skabt i Guds billede. Før Gud blev gammel og gnaven og verden forstenede. Derfor vil der altid være begejstring og ungdom i en sund kirke. Mangler den, så er det ikke, fordi der mangler opgejlet underholdning, men fordi kirken selv er blevet gammel og gigtsvag. Fordi de åndelige vækstkræfter bliver hæmmet og fornægtet. Fordi Helligånden ikke længere bydes op til dans. Fordi tonen fra himlen er døet hen, længe før præsten klapper i og kirkeorglet klinger ud.

Hver eneste gudstjeneste er i virkeligheden en kosmisk bryllupsfest, en liturgisk-poetisk fejring af skabelsesdramaet med stadigt skiftende betoninger. $\mathrm{Og}$ for overhovedet at kunne rumme et så overvældende og altomvæltende budskab, for overhovedet at kunne udtrykke så stor og udelt en begejstring. som hele denne kosmiske bryllups-ekstase og elskovs-harmoni helt naturligt fremkalder, så må menigheden selv blive til en ekstatisk Helligånds-overstrømmende enhed - et guddommeligt dannelses-fællesskab, det som Grundtvig kalder for den levende Sang-Skole eller Skolen for Sang:

\begin{abstract}
Derfor maa Kiærligheden mellem Forældre og Børn og den ægteskabelige Kiærlighed mellem Mand og Kvinde i det gamle Menneske-Liv, for saavidt den findes og saavidt den gaaer, være aldeles eensartet med Kiærligheden mellem den himmelske Fader og hans jordiske Børn, og den cegteskabelige Kiærlighed mellem Christus og hans Menighed i det ny Menneskeliv, og, ligesom Herren selv har sagt os, at vi maae blive som Menneske-Børn, før vi kan gienfødes til Guds-Børn, saaledes vil Herrens Aand sige os, at vi maa blive som menneskelige Egtefaller, før vi kan indlemmes i det store Fallesskab med Herren som en Brud med sin Brudgom, og en Husfrue med sin Ægtemand (VU VI, 131).
\end{abstract}

Således bliver ægteskabet hos Grundtvig forvandlet til et sindbillede. Kønslivet bliver til den jordnært pragmatiske grundmodel for gudslivet. Kønsforholdet mellem ægtemand og husfrue er den dagligdagens læst, hvorover den menneskelige kærlighed, "for så vidt som den findes og så langt som den når", gradvis og lignelsesvis kan bearbejdes, udhamres, udvikles og udvides i retning af den guddommelige. 
Der er på ingen måde tale om, at Grundtvig overser den regimentale grundforskel mellem menneskeligt og guddommeligt. Forskellen mellem det gammel-menneskelige og det nymenneskelige, mellem den hedenske og den kristnede eros, mellem det jordiske og det himmelske bryllup, markeres klart og tydeligt. Men det er lignelsen og ligheden, den reelle og potentielle ligedannethed imellem de forskellige skalaer og intensiteter af vores kærlighedsrelationer, som er den altafgørende faktor for Grundtvig. For det er den, og ikke forskellen, der giver vækstbetingelser for tro og håb, og baner vejen for den menneskelige vækst ind i kærlighed.

Grundtvig ville aldrig benægte, at formindskelserne, afstandene, vanskelighederne og overgangene findes. Ellers ville mennesket jo allerede være fuldkomment og historien forbi. At syndefaldet er en jordisk, det vil sige en påtrængende menneskelig, økologisk og kosmologisk realitet burde være åbenbart for enhver. Verden er forrykket fra sit oprindelige ligevægtsstade, en åndelig sammentrækning og deformation har fundet sted, og forrykkelsen er blevet vores egen natur. Den faldne og ligeglade menneskehed er med Grundtvigs rammende udtryk forrykt. Men ved at tage udgangspunkt lige der, hvor kærligheden gror, gør han overgangene glidende og modstanden mere overkommelig for dem, som elsker og tror. Helligånden er allestedsnærværende som guddommens fremstrakte hånd. Menneskekærligheden (eros) behøver ikke at stige lodret ud af kroppen og ind i himlen for at blive gudsvelsignet. Opstigningen kan til enhver tid begynde med det nærmeste og mest påtrængende og kropsnære: Ægteskabets indre spændinger og modstande, elskovskunsten, børneavlen og yngelplejen, arbejdsfordelingen, magtforholdene og kønskonflikterne. Husholdningen (oikos), alle hverdagens banale øvelser og prøvelser, fremstår hos Grundtvig som selve prøvestenen for de gode viljer. Både i dagligdagens bogstavelige betydning og $\mathrm{i}$ ordet videre økonomiske, økologiske og økumeniske betydninger er det den kærligheds-orden, som hersker i hjemmet, som danner grundstenen for det evige liv.

\section{Forkortelser}

Danskeren I-IV: N. F. S. Grundtvig (1848-51), Danskeren, et Ugeblad, bind 1-4, København.

DV I-IV: N. F. S. Grundtvig (1816-19), Danne-Virke, et Tids-Skrift, bind 1-4, København.

GSV I-VI: Th. Balslev et al. (udg.) (1944-64), Grundtvigs Sang-Vaerk. Samlet Udgave, bind 1-6, København. 
US I-X: Holger Begtrup (udg.) (1904-09), Nik. Fred. Sev. Grundtvigs Udvalgte Skrifter, bind 1-10, København.

$V U$ I-X: Georg Christensen og Hal Koch (udg.) (1940-49), N. F. S. Grundtvigs Vaerker i Udvalg, bind 1-10, København.

\section{Litteraturliste}

\section{Varker af Grundtvig}

Balslev, Th. et al. (1944-64), Grundtvigs Sang-Vark til den danske Kirke. Samlet Udgave, bind 1-6, København.

Begtrup, Holger (udg.) (1904-09), Nik. Fred. Sev. Grundtvigs Udvalgte Skrifter, bind 1-10, København.

— (udg.) (1924), N. F. S. Grundtvigs Vartovs-Prcedikener 18391860, København.

Brandt, J. C. (udg.) (1880), N. F. S. Grundtvigs Sidste Prcedikener $i$ Vartov Kirke 1861-72, København.

Bugge, K. E. og Vilh. Nielsen (udg.) (1983), N. F. S. Grundtvig (1834), Statsmaessig Oplysning: Et udkast om samifund og skole København.

Grundtvig, børnebørn (udg.) (1920), N. F. S. Grundtvigs Breve til hans Hustru under Englandsreiserne 1829-1831, København.

Grundtvig, N. F. S. (1816-19), Danne-Virke, Et Tids-Skrift, bind 1-4, København.

— (1817), "Om Sandhed, Storhed og Skiønhed" i $D V$ III, 17-62.

— (1842), Kvinde-Evangeliet, ("I Herrens Huus er Varmen") i GSV III, nr. 205, 399-409.

—_ (1851), “'Besøget' af Clara Raphael” i Danskeren IV, nr. 41, 641652.

— (1855-61), "Den Christelige Børnelærdom" i $V U$ VI, 1-273.

— (1870), "Som Maanen skinner af Solens Glands" i GSV V, nr. 349, København, 626-627.

Grundtvig, Svend (udg.) (1880-1930), N. F. S. Grundtvigs Poetiske Skrifter, bind 1-9, København.

— (udg.) (1882), Grundtvig og Ingemann. Brevvexling 1821-1859, København.

Holm, Jette et al. i samarbejde med Chr. Thodberg (udg.) (2003), Grundtvig Proedikener $i$ Vartov 1839-42, bind 1-4, København.

Johansen, Steen og Høirup, Henning (udg.) (1983), Grundtvigs

Erindringer og Erindringer om Grundtvig, København. 2. opl.

Johansen, Steen (udg.) (1956), Taler paa Marielyst Højskole 1856-71, København.

Thodberg, Chr. (udg.) (1983-86), N. F. S. Grundtvigs Pradikener: 1822-26 og 1832-39, bind 1-12, København. 


\section{Værker af andre forfattere}

Allchin, A. M. (2002), Grundtvigs Kristendom. Menneskeliv og Gudstjeneste, overs. af Jakob Balling, Århus.

Appel, Elin (1978), Kvindens genmaele, København.

Berdyaev, Nicolas (1945), The Destiny of Man, Glasgow University Press.

(1992 (1935)), Freedom and the Spirit, New Hampshire.

(1962 (1936)), The Meaning of History, New York.

(1944), Slavery and Freedom, London.

— (1946), Spirit and Reality, London.

- (2001) "The Doctrine of Sophia and the Twofold-Being of Man Jakob Boehme and Russian Sophiological Currents" i Robert J. Fass (ed.): The Divine Couple - A Christian Book of Mystery on Eros-Love, Minnesota.

Borum, Poul (1983), Digteren Grundtvig, København.

Brandt-Nielsen, E. (1993), "Grundtvig og det kvindelige", Dansk udsyn, årg. 72, nr. 3 .

Brock, Ann Graham (2003), Mary Magdalene, The first Apostle - The Struggle for Authority, Harvard.

Brown, Raymond E. (1979), The Community of the Beloved Disciple, New York.

Bukdahl, Jørgen (1948), Rusland bag Stalin, Askov.

- (1947), Norden og Europa, København.

Bulgakov, Sergei (1993 (1937)), Sophia - The Wisdom of God, New York.

Chrysostom, St. John (2003), On Marriage and Family Life, Crestwood, NY.

Ditlevsen, Kirsten (1991), “Grundtvig og jomfru Maria", Vartovbogen, København, 29-48.

- (1991) "Maria - et forbillede for kristne? Grundtvigs syn på Jomfru Maria", Grundtvig-Studier 1991, 112-133.

Eckhart, Mester (1983), Matthew Fox (ed.), Meditations with Meister Eckhart, Rochester, Vermont.

Elbek, Jørgen (1989), Moder, Søster, Elskte, Frydenlund.

- (1998), "Guds Datter" i Arhundredets bro, Århus, 7-12.

Engberg, Poul og Bukdahl, Jørgen (1945), Grundtvig og Videnskaben, Askov.

Engberg, Poul (1993), Grundtvig mellem øst og vest-Mellem Sophia og Ratio, Herning.

Evdokimov, Paul (1994), Woman and the Salvation of the World - A Christian Anthropology on the Charisms of Women, Crestwood, New York. 
- (2001), The Sacrament of Love - The Nuptial Mystery in the Light of the Orthodox Tradition, Crestwood, New York.

- (1998), Ages of the Spiritual Life, New York.

Florensky, Pavel (1997), The Pillar and Ground of the Truth, Princeton.

Fox, Matthew (2000 (1983)), Original Blessing, Santa Fe.

- (1988), The Coming of the Cosmic Christ, San Francisco.

Frye, Northrop (1992), Den store Kode - Bibelen og Litteraturen, Århus.

Hartby, Inger (1999), Højskolekvinden - mor, søster, datter: Højskolekvindens kulturelle status og livsvilkår 1870-1920, Odense.

- (2003), Højskolens Døtre: en analyse af højskolekvinders livsvilkår og kulturelle status, samt folkehøjskolens forvaltning af køn 1920-2000, ph.d.-afhandling, Odense.

Heggem, Synnøve (2000), "Grundtvigs kvinnesalmer, kjærlighetens kjønnsbestemte sang”, Dansk Kirketidende, årg. 152, nr. 3, København, 36-39.

_ (2004), Kjarlighetens makt, maskerade og mosaikk En lesning av N. F. S. Grundtvigs Sang-Vark til den Danske Kirke, Disputats, Oslo.

Jonas, Uffe (1997), "Tiden før Selvet - Grundtvig og det historiske menneske" i Ove Korsgaard (red.), En Orm - en Gud: Om Mennesket $i$ Verden, Odense, 105-152.

— (2000), Det håndgribelige selv - Grundtvigs lcere om kroppen og sanserne, Forsker-seminar, Vartov, København.

— (2001), "Jørgen Bukdahl og Europas Sjæl - om tilblivelsen af det europæiske menneske" i Ove Korsgaard (red.), Poetisk Demokrati, København, 83-107.

- (2001), "Selvomsorgens Etik - Michel Foucault og det selvdannende menneske" i Ove Korsgaard (red.) Poetisk Demokrati, København, 163-192.

— (2003), "Poetisk Videnskab - Grundtvigs universitetsdrøm som kosmopolitisk dannelsesprojekt" i Ole Vind og Hanne Sanders (red.) Grundtvig - nyckeln till det danska, Göteborg - Stockholm, 225-281.

Kvam, Bjørn Olav Grüner (2004), Zohar. Stråleglansens Bok - Fra den jødiske kabbalah, Oslo.

Larsen, Ejvind (1983), Det levende ord, København.

- (1984), "Den påtrængende Grundtvig" i Johs. H. Christensen et al. (red.), De levendes Land, København, 76-114.

- (1991), "Folkestyrets mystik - Den danske folkehøjskole, andelsbevægelsens tredje vej og Guds datter Sofia" i Else-Marie Boyhus (red.), Midt i Højskolen, København. 
Leloup, Jean-Yves (2004), The Gospel of Philip, Rochester, Vermont. Muhl, Lars (2004), Maria Magdalene, København.

Nielsen, Erik A. (1998), "Poetisk Teologi" i Solens Fødsel - seks tekster om kristendommens hemmeligheder, København.

Nielsen, S. (1956), Grundtvig ønskede kvindelige prcester i Aalborg Stıftstidende 13.02.56.

Pagels, Elaine (1986), Tabernes Evangelier, København.

- (1989), Adam, Eva og Slangen, København.

- (1979), "What became of God the Mother? - Conflicting Images of God in Early Christianity" i Carol Christ og Judith Plaskow (eds), Womanspirit Rising, San Francisco, 107-119.

Pedersen, Jørgen (1991), "Den dybe sammenhæng - om Grundtvigs salme 'Hil dig Frelser og Forsoner' som gengivelse af den cisterciensiske passions-rhytmus 'Salve, mundi salutare"' i Jørgen Pedersen, Fra Augustin til Johs. V. Jensen, København, 165-203.

Pedersen, Kim Arne (2005), Kompendium om Grundtvigs kvindesyn, Vartov, København.

Schäfer, Peter (2002), Mirror of his Beauty - Feminine Images of God from the Bible to the Early Kabbalah, Princeton.

Schubart, Walter (1939), Dostojevski og Nietzsche, København.

- (1969), Religion og Erotik, overs. af Mogens Boisen, København.

Sherrard, Philip m.fl. (1981), Philokalia - The Complete Text vol. IIV.

Skyum-Nielsen, Peder (2006), "De danske værdier har fået hjerteforkølelse", Politiken, 2. maj 2006, 2. sekt.

Solovjov, Vladimir (1997), Korlighedens Mening, København.

— (1995), Lectures on Divine Humanity, New York.

Stevns, Magnus (1950), "Kvinden i Grundtvigs Salmer" i Fra Grundtvigs Salmevcerksted, København, 72-85.

Teilhard de Chardin, Pierre (1967), Writings in Time of War, London.

- (1970), Activation of Energy, London.

- (1969), Christianity and Evolution, London.

Vind, Ole (1999), Grundtvigs Historiefilosofi, København.

—_ (1999), "Grundtvig og kvindesagen”, Højskolebladet, årg. 124, nr. 8.

Whitehead, A. N. (1995), Religionens tilblivelse, København.

Noter

Af de væsentligste bidrag skal nævnes Magnus Stevns' (1950), Kvinden $i$ Grundtvigs Salmer. Synnøve Heggem (2000), Grundtvigs kvinnesalmer, kjorlighetens kjønnsbestemte sang, samt disputatsen, Kjorlighetens makt, maskerade og mosaikk En lesning av N. F. S. Grundtvigs Sang-Vork til 
den Danske Kirke, (2004). Visdomstænkningen, det sophianiske og dermed kvindelige grundmotiv hos Grundtvig, har imidlertid aldrig fået blot tilnærmelsesvis den opmærksomhed, som dets altgennemgribende betydning berettiger. Men er bl.a. berørt af Jørgen Pedersen i artiklen, Den dybe sammenhoeng (1991). Også hos Jørgen Elbek (1989 og 98), Poul Behrendt (1974), Erik A. Nielsen (1980 og 98) og Ejvind Larsen (1991) findes der væsentlige udkast til en sådan forståelse. Endvidere skal nævnes højskole-folkene Jørgen Bukdahl (Jonas 2001) og Poul Engberg (1993) som dem, der måske mest vedholdende har peget på betydningen af den sophianiske og den østkirkelige dimension i Grundtvigs tænkning. Det er således Engberg og Bukdahl (1947 og 48), der har peget på de russiske slavofiler (Kirejevsky og Chomjakov) og dermed indirekte også på sophianerne (Soloviev (1995 og 97), Bulgakov (1993), Florensky (1997) og Berdyaev (1945 og 62)) som de måske allernærmeste slægtninge til Grundtvig i filosofisk og historie-filosofisk henseende. Berdyaevs The Meaning of History indeholder således det nærmeste, man kan komme til essensen af Grundtvigs kristne historie-filosofi, skønt den af uransagelige grunde slet ikke indgår i Ole Vinds afhandling (1999). Engberg og Bukdahl har peget på den østkirkelige forbindelse, skønt deres perspektiv ikke har været universelt nok til at uddybe den, men først og fremmest båret af folkelighedens og mellem-folkelighedens interesse.

Jeg har tidligere redegjort for epistemologien bag de forskellige grundtvigske skolebyggerier, jf. Jonas 2003, $225 \mathrm{ff}$.

Jf. Katrine Winkel Holm (red.) (2005): Og Gud velsignede dem - fire essays om kirke, kerlighed og agteskab. Heri indgår Grundtvigs ægteskabsteologi som et selvstændigt kapitel af sognepræst Jesper Høgenhaven. Men køns-spørgsmålet behandles kun inden for den naturlige teologis moralistiske perspektiv. Grundtvigs storslåede skabelsesteologiske og eskatologiske kønsbetragtninger, som i virkeligheden er bestemmende for hele hans dybsindige kønsteologi, er udeladt af synsfeltet. Målet ifølge forfatteren er en Grundtvig befriet for de "vitalistiske eller kærlighedsidealistiske tolkninger hos hans efterfølgere" (s. 117). For at gennemføre dette kunststykke påberåbes højregrundtvigianeren Otto Møller (1831-1915), som nok "fornemmer at det erotiske har fået en fremtrædende plads, der ikke er af det gode". Og " $\mathrm{Al}$ den snak om "den hjertelige kvinde' kunne vistnok være tilstrækkelig nu", som han så fromt og håbefuldt formulerer det. Men en Grundtvig uden vitalisme og høje kærlighedsidealer, dvs. uden eros, uden livs-glæde, livs-oplysning, livsoplivelse, en Grundtvig uden sans for Helligåndens befrugtende gerninger og den poetiske skaberfryd, uden kvindeglæden, og den uendelige optimisme på kærlighedens, kønnenes og den gensidige sammensmeltnings vegne: Det er slet ingen Grundtvig, men en hjemmedyrket teologisk vissenpind. Holms og Høgenhavens projekt er en fornægtelse af selve livsåren i Grundtvigs tænkning og en tilsvarende hyldest til dødbideriet $\mathrm{i}$ den danske folkekirke. Grundtvigs omfattende eros-forståelse, som er 
bestemmende for hele hans livsoplysnings-projekt, hvor det bogstaveligt talt er "lysten der driver værket", fortrænges til fordel for den misogyne, kropsforsagende og anti-erotiske augustinske morallære (som den også genfindes hos Kierkegaard). Tilbage står en fuldkommen uigenkendelig Grundtvig skåret til efter en negativ kors-teologis afsjælede og vindtørre verdenssyn. Så trods emnets væsentlighed - ægteskabets nutidige status, kønnets betydning, kirkens traditioner og homoseksuelles rettigheder osv. - hæver hele diskussionen sig aldrig ud over det banale.

4 I hovedværket Original Blessing (1983) har Matthew Fox opstillet en annoteret anetavle over skabelses-spiritualitetens væsentligste repræsentanter gennem tiderne. Grundtvig indgår af gode grunde ikke. Men havde forfatteren kendt til ham, ville han uden tvivl have kunnet indtage sin prominente plads på parnasset, sammen med adskillige af sine største forbilleder.

5 Jf. f.eks. S. Nielsen (1956), Grundtvig ønskede kvindelige prcester, eller Bodil Koch (1968), Grundtvig Luther og agteskabet. 